\title{
PROBLEM CONFRONTATION OF THE FFS FARMERS IN PARTICIPATING FARMER FIELD SCHOOL TRAINING SESSION
}

\author{
D. Roy ${ }^{1 *}$, M. G. Farouque ${ }^{2}$ and M. Z. Rahman ${ }^{3}$ \\ Department of Agricultural Extension Education, Bangladesh Agricultural University \\ Mymensingh-2202, Bangladesh
}

\begin{abstract}
The study was conducted to identify and describe the problems of FFS farmers in participating FFS training sessions. Data and information were collected from 100 FFS farmers of selected three unions of Muktagacha Upazila of Mymensingh district in Bangladesh from 10 to 30 April, 2013. Among ten selected problems "Inadequate trials and training materials" got the highest score (PCI-176) while "Biasness in trainee selection" got the lowest score (PCI-48). The highest proportion of the FFS farmers (53\%) had low problem in participating FFS training session, while $40 \%$ and $7 \%$ had medium and high problem, respectively. Findings indicate that a majority i.e. more than four fifth of the FFS farmers faced low to medium problems in participating FFS training sessions. The selected characteristics of the FFS farmers, such as year of schooling, farming experience, extension media contact, risk orientation and knowledge on soil and crop management showed significantly negative relationship with problem confrontation in participating FFS training sessions by the FFS farmers. Therefore, it can be mentioned that there is no significant problems associated with the FFS training sessions. So, necessary steps need to be taken to enhance the existing activities of FFS that could improve the sustainable crop production as well as the livelihood of the FFS farmers.
\end{abstract}

Key Words: Farmer field school, FFS farmer, Problem confrontation, Training

\section{INTRODUCTION}

Farmer Field School (FFS) is considered as an extension approach where the farmers are being trained up about different aspects of crop production especially management of soil and crop in a low cost and environment friendly means through a season long training program.

FFS is a very popular extension and education approach throughout the world. Now a days, about 78 countries are implementing this approach (Braun et al., 2006), although in different forms and with varying focus depending on the national context. The aim of an FFS is to build farmers' capacity to analyze their production systems, identify problems, test possible solutions and eventually adopt the practices most suitable to their farming system. The

1Lecturer, $2 \& 3$ Professors, Department of Agricultural Extension Education, Bangladesh Agricultural University, Mymensingh-2202, Bangladesh

*Corresponding author (Email: droyagext@bau.edu.bd) 
knowledge acquired during the learning process enables farmers to adapt their existing technologies to be more productive, profitable, and responsive to changing conditions, or to test and adopt new technologies. The first FFS was conducted in 1989 in the rice fields of Indonesia. FFSs were designed to educate farmers on the principles of "Integrated Pest Management" (IPM) in order to deal with major outbreaks of Brown Plant Hopper (BPH) (Bijlmakers, 2011). In Bangladesh, the FFS was first used in the early 1990's in FAO implemented Integrated Pest Management (IPM) program. Initially, FFSs organized by Department of Agricultural Extension (DAE) followed the "original" rice IPM FFS curriculum to a large extent, with a strong focus on managing pest problems and with the aim of reducing pesticide related problems. But with the passage of time the curriculum has been revised and improved several times. Gradually this has changed to a more holistic approach of crop production i.e. Integrated Crop Management (ICM).

According to Saini (2008), FFS is a hands-on training method in which farmers test management methods/production technologies for themselves and learn concepts directly. In a FFS, the participants are supposed to get together in a weekly basis. FFSs are "school without walls" where a group of farmers meet weekly with facilitators (Davis and Place, 2003).They observe, analyze and make probable solutions against any farming problem. In this way, they become active learner and creative decision maker about their farming problems. Although FFS has been launched in our country before about two decades from today, the FFSs and number of FFS farmers are few. There may have different reasons behind this but one of the main could be problems associated with FFS training sessions. Considering the above facts, the researchers undertook this research and formulated the following objectives:

i. to identify and describe the problems of the FFS farmers in participating FFS training sessions;

ii. to describe the selected characteristics of the FFS farmers; and

iii. to explore the relationships between the selected characteristics of the FFS farmers and their problem confrontation in participating FFS training sessions.

\section{METHODOLOGY}

\section{Study area, population and sampling}

The study was conducted in three unions of Muktagacha Upazila under Mymensingh district. The study area was selected purposively for investigation, because highest number of ICM-FFSs has been conducted there. There were five ICM-FFSs and the male farmers (125) of the ICM-FFSs of the selected unions of Muktagacha Upazila were considered as the population of the study. The total list of male participants of ICM-FFSs was obtained from the office of the Upazila Agriculture Officer of Muktagacha Upazila. Simple random sampling was used in selecting the respondents from each ICM-FFS and a total of 100 ICMFFS farmers were selected as sample size from the population i.e. about eighty (80) percent of the total population was the sample size of the study. The empirical data were collected using personal interview method along with Focus Group Discussions during the period of 10 to 30 April, 2013. Before collecting final data, pre-testing of the interview schedule was made to locate any defects regarding the questions and statements. 


\section{Selection and measurement of explanatory and focus variables}

The explanatory variables of the study were 10 selected characteristics of the FFS farmers. These were age, year of schooling, household size, farm size, farming experience, engagement with FFS, annual family income, extension media contact, risk orientation and knowledge on soil and crop management. Most of the explanatory variables were measured by developing scales based on the raw scores (Table 1 ).

Table 1. Characteristics profile of the FFS farmers

\begin{tabular}{|c|c|c|c|c|c|c|c|}
\hline \multirow{2}{*}{$\begin{array}{l}\text { Characteristics } \\
\text { (Measuring units) }\end{array}$} & \multicolumn{2}{|c|}{ Score ranges } & \multirow[t]{2}{*}{ Categories } & \multicolumn{2}{|c|}{ FFS farmers } & \multirow[t]{2}{*}{ Mean } & \multirow[t]{2}{*}{ SD } \\
\hline & Possible & Observed & & No. & $\%$ & & \\
\hline \multirow[t]{3}{*}{ Age (Years) } & unknown & $20-63$ & Young (up to 35) & 29 & 29 & 43.67 & 11.929 \\
\hline & & & Middle aged (36-50) & 41 & 41 & & \\
\hline & & & Old $(>50)$ & 30 & 30 & & \\
\hline \multirow{4}{*}{$\begin{array}{l}\text { Year of schooling } \\
\text { (Total years of } \\
\text { schooling) }\end{array}$} & unknown & $0-17$ & Illiterate $(0)$ & 39 & 39 & 5.22 & 4.875 \\
\hline & & & Primary (1-5) & 15 & 15 & & \\
\hline & & & Secondary (6-10) & 35 & 35 & & \\
\hline & & & Above secondary $(>10)$ & 11 & 11 & & \\
\hline \multirow{3}{*}{$\begin{array}{l}\text { Household size } \\
\text { (No. of members) }\end{array}$} & unknown & $2-13$ & Small (up to 4) & 31 & 31 & 5.47 & 1.936 \\
\hline & & & Medium (5-8) & 64 & 64 & & \\
\hline & & & Large $(>8)$ & 5 & 5 & & \\
\hline \multirow{5}{*}{$\begin{array}{l}\text { Farm size } \\
\text { (Hectare) }\end{array}$} & unknown & $0.05-2.61$ & Landless (<0.02 ha) & 0 & 0 & 0.706 & 0.567 \\
\hline & & & Marginal (0.02-0.2 ha) & 11 & 11 & & \\
\hline & & & Small (0.21-1.0 ha) & 65 & 65 & & \\
\hline & & & Medium (1.01-3.0 ha) & 24 & 24 & & \\
\hline & & & Large (>3.0 ha) & 0 & 0 & & \\
\hline \multirow{3}{*}{$\begin{array}{l}\text { Farming experience } \\
\text { (Years) }\end{array}$} & unknown & $6-45$ & Less (up to 15) & 33 & 33 & 22.47 & 9.570 \\
\hline & & & Medium (16-30) & 47 & 47 & & \\
\hline & & & $\operatorname{High}(>30)$ & 20 & 20 & & \\
\hline \multirow{3}{*}{$\begin{array}{l}\text { Engagement with FFS } \\
\text { (Years) }\end{array}$} & unknown & $1-5$ & Low (up to 2) & 20 & 20 & 3.16 & 1.401 \\
\hline & & & Medium (3-4) & 60 & 60 & & \\
\hline & & & $\operatorname{High}(>4)$ & 20 & 20 & & \\
\hline \multirow{3}{*}{$\begin{array}{l}\text { Annual family income } \\
\left(000^{\prime} \text { Taka) }\right.\end{array}$} & unknown & $17-460$ & Low (up to 153) & 64 & 64 & 155.47 & 106.92 \\
\hline & & & Medium (154-305) & 24 & 24 & & 6 \\
\hline & & & High $(>305)$ & 12 & 12 & & \\
\hline \multirow{3}{*}{$\begin{array}{l}\text { Extension media } \\
\text { contact (Scores) }\end{array}$} & $0-30$ & $4-25$ & Low (up to 10) & 20 & 20 & 14.26 & 4.743 \\
\hline & & & Medium (11-20) & 73 & 73 & & \\
\hline & & & High $(>20)$ & 7 & 7 & & \\
\hline \multirow{3}{*}{$\begin{array}{l}\text { Risk orientation } \\
\text { (Scores) }\end{array}$} & $6-18$ & $7-17$ & Low (up to 9) & 11 & 11 & 13.21 & 2.500 \\
\hline & & & Medium (10-13) & 36 & 36 & & \\
\hline & & & $\operatorname{High}(>13)$ & 53 & 53 & & \\
\hline \multirow{3}{*}{$\begin{array}{l}\text { Knowledge on soil and } \\
\text { crop management } \\
\text { (Scores) }\end{array}$} & $0-40$ & $11-37$ & Low (up to 13) & 4 & 4 & 21.44 & 5.292 \\
\hline & & & Medium (14-26) & 77 & 77 & & \\
\hline & & & High $(>26)$ & 19 & 19 & & \\
\hline
\end{tabular}


Problem confrontation of the FFS farmers in participating FFS training session was the focus variable of the study. Researcher used a 4-point rating scale for measuring problem confrontation score. The farmers were asked to give their response against 10 selected problems which they faced in participating FFS training sessions. The weights assigned for each response were: 3 for high confrontation, 2 for medium confrontation, 1 for low confrontation and 0 for not at all.

The problem confrontation score was obtained by adding weights of responses of the problems and therefore, the problem confrontation score could vary from 0 to 30 , where 0 indicating 'no problem' and 30 indicating 'highest problem'.

For making rank order, Problem Confrontation Index (PCI) was computed as used by Hossain and Miah, 2011. The PCI was computed by using the following formula:

$\mathrm{PCI}=\mathrm{Ph} \times 3+\mathrm{Pm} \times 2+\mathrm{P} 1 \times 1+\mathrm{Pn} \times 0$

Where,

$\mathrm{PCI}=$ Problem Confrontation Index

$\mathrm{Ph}=$ No. of the respondents expressed problem as "high"

$\mathrm{Pm}=$ No. of the respondents expressed problem as "medium"

$\mathrm{Pl}=\mathrm{No}$. of the respondents expressed problem as "low"

$\mathrm{Pn}=$ No. of the respondents expressed problem as "not at all"

Thus, the PCI of individual problem could range from 0 to 300, where 0 indicating 'no' problem confrontation and 300 indicating 'high' problem confrontation.

\section{FINDINGS AND DISCUSSION}

\section{Selected characteristics of the FFS farmers}

Problem confrontation of the FFS farmers becomes affected by their characteristics. In this study, ten selected characteristics were considered. The characteristics profile of the FFS farmers has been presented in the Table 1.

Data in Table 1 reveal that majority of the FFS farmers (41\%) were middle-aged and considerable proportion of the FFS farmers (39\%) was illiterate. The highest proportion of the FFS farmers (64\%) had the medium sized household while the farm size of the highest proportion of the FFS farmers (65\%) were small. Data also reveal that the majority of the FFS farmers $(47 \%)$ had medium farming experience while the highest proportion of the FFS farmers $(60 \%)$ had medium engagement with FFS. Data related to annual family income indicate that the highest proportion of the FFS farmers (64\%) were in low income category but a satisfactory proportion of the FFS farmers $(73 \%)$ had medium extension media contact. Data also reveal that more the half of the FFS farmers (53\%) were highly risk oriented while the highest proportion of the FFS farmers $(77 \%)$ had medium level of knowledge on soil and crop management. 


\section{FFS Farmers' problems in participating FFS training sessions}

FFS farmers' problems in participating FFS training session were measured in two ways, i.e., i) by placing the problematic aspects in rank order and ii) by measuring the overall problem confrontation.

For determining the extent of confrontation of the individual problem rank order was made computing Problem Confrontation Index (PCI). According to the rank order (Table 2), the top five problems with highest PCI score have been described here.

Table 2. Ten selected problems along with problem confrontation index and rank order Note: $P C I=$ Problem confrontation index

\begin{tabular}{|c|c|c|c|c|c|c|c|}
\hline \multirow{2}{*}{\multicolumn{2}{|c|}{ Problems }} & \multicolumn{4}{|c|}{ Extent of problem confrontation } & \multirow[t]{2}{*}{ PCI } & \multirow{2}{*}{$\begin{array}{l}\text { Rank } \\
\text { order }\end{array}$} \\
\hline & & High & Medium & Low & Not at all & & \\
\hline 1. & Inadequate trials and training materials & 12 & 58 & 24 & 6 & 176 & 1 \\
\hline 2. & Irregularity of farmers participation & 18 & 30 & 50 & 2 & 164 & 2 \\
\hline 3. & $\begin{array}{l}\text { Difficulties in participating in the } \\
\text { training session during the peak period } \\
\text { of cultivation }\end{array}$ & 6 & 42 & 42 & 10 & 144 & 3 \\
\hline 4. & $\begin{array}{l}\text { Lack of active participation of the female } \\
\text { beneficiaries in the FFS }\end{array}$ & 12 & 34 & 36 & 18 & 140 & 4 \\
\hline 5. & $\begin{array}{l}\text { Gradual reduction of members in the } \\
\text { training sessions }\end{array}$ & 6 & 30 & 40 & 24 & 118 & 5 \\
\hline 6. & $\begin{array}{l}\text { Lack of training allowances from the } \\
\text { authority }\end{array}$ & 2 & 24 & 52 & 22 & 106 & 6 \\
\hline 7. & Time consuming training session & 2 & 20 & 32 & 46 & 78 & 7 \\
\hline 8. & Irregular presence of trainers & 5 & 10 & 30 & 55 & 65 & 8 \\
\hline 9. & Lack of skilled trainers & 2 & 22 & 14 & 62 & 64 & 9 \\
\hline & Biasness in trainee selection & 8 & 6 & 12 & 74 & 48 & 10 \\
\hline
\end{tabular}

Table 2 shows that "Inadequate trials and training materials" got the highest score (PCI-176) and hence was considered as the $1^{\text {st }}$ ranked problem. During training, the FFS practitioners do not provide sufficient training materials to the FFS famers, as a result, they need to form some groups but they want to practice individually in the field situation. The FFS farmers opined that there was lack of adequate trials or adequate trials seemed to be not possible due to adverse field situation. The problems may also arise when a training of trainer session does not provide enough opportunities for participants to master the FFS process. In other instances, the training of trainer sessions might not follow experiential learning process (Pontius et al., 2002). According to Khatam et al. (2010), this problem got the $11^{\text {th }}$ position (out of fifteen) in the rank order. The problem "Irregularity of farmers' participation" got the $2^{\text {nd }}$ highest scores (PCI-164) which was considered as the 2nd ranked problem. This may be due to the adverse weather condition and also due to lack of interest of the farmers in participating in training sessions. According to Khatam et al. (2010), this problem got the 10th position (out of fifteen) in the rank order. The problem "Difficulties in 
participating in the training session during the peak period of cultivation" got the $3^{\text {rd }}$ highest scores (PCI-144) and hence it was considered as the $3^{\text {rd }}$ ranked problem. This may be due to lack of proper management of time during training period. Khatam et al. (2010) found this problem got $3^{\text {rd }}$ position (out of fifteen) in the rank order. The problem "Lack of active participation of the female beneficiaries in the FFS" got the $4^{\text {th }}$ highest scores (PCI140 ) and hence it was considered as the $4^{\text {th }}$ ranked problem. This may be due to social barriers prevailing in the rural areas. Bijlmakers and Islam (2007) pointed out that the FFS curricula were not addressing the real needs of the female in participating trainings. The problem "Gradual reduction of members in the training sessions" got the $5^{\text {th }}$ highest scores (PCI-140) which was considered as the $5^{\text {th }}$ ranked problem. This is may be due to the farmers business with other activities rather than agricultural activities or lack of interest to participate in the training sessions.

There were another five problems among them "Biasness in trainee selection" got the lowest score (PCI-48) which was considered as the $10^{\text {th }}$ ranked problem and got the last position in the order. This may be due to the proper selecting criteria of farmers followed by the FFS practitioners.

The problem confrontation scores of the FFS farmers ranged from 3 to 24 against a possible range of 0-30, with an average 10.84 and standard deviation 5.212. Based on the problem confrontation score, the FFS farmers were classified into three categories i.e. low, medium and high problem confrontation. Distribution of the respondents according to their problem confrontation has been shown in Table 3.

Table 3. Distribution of the respondents according to their problem confrontation in participating FFS training sessions

\begin{tabular}{|c|c|c|c|c|c|c|}
\hline \multicolumn{2}{|c|}{ Score range } & \multirow{2}{*}{$\begin{array}{c}\text { Categories of FFS farmers according } \\
\text { to problem confrontation }\end{array}$} & \multicolumn{2}{|c|}{ FFS farmers $(n=100)$} & \multirow[t]{2}{*}{ Mean } & \multirow{2}{*}{$\begin{array}{l}\text { Standard } \\
\text { deviation }\end{array}$} \\
\hline Possible & Observed & & Number & Percent & & \\
\hline \multirow[t]{4}{*}{$0-30$} & $3-24$ & Low (up to 10) & 53 & 53 & 10.84 & 5.212 \\
\hline & & Medium (11-20) & 40 & 40 & & \\
\hline & & High (above 20) & 7 & 7 & & \\
\hline & & Total & 100 & 100 & & \\
\hline
\end{tabular}

Data presented in the Table 3 show that the highest proportion of the FFS farmers (53\%) had low problem in participating FFS training session, while $40 \%$ and $7 \%$ had medium and high problem, respectively. The findings indicate that four fifth of the FFS farmers faced low to medium problems in participating in FFS training sessions and thus, it might be positive sign to the effectiveness of FFS.

\section{Relationship between the selected characteristics of the FFS farmers and problem confrontation}

Pearson's product moment co-efficient of correlation ( $\mathrm{r}$ ) was used to ascertain the relationships between the selected characteristics of the FFS farmers and problem confrontation. The correlation has been shown in the Table 4. 
Table 4. Correlation between explanatory and focus variables $(n=100)$

\begin{tabular}{|c|c|c|c|c|}
\hline \multirow[t]{2}{*}{$\begin{array}{c}\text { Focus } \\
\text { variable }\end{array}$} & \multirow[t]{2}{*}{ Explanatory variables } & \multirow[t]{2}{*}{$\begin{array}{c}\text { Correlation } \\
\text { co-efficient (r) values with } 98 \mathrm{df}\end{array}$} & \multicolumn{2}{|c|}{$\begin{array}{c}\text { Tabulated } \mathrm{r} \text { values } \\
\text { with } 98 \mathrm{df}\end{array}$} \\
\hline & & & 0.05 level & 0.01 level \\
\hline \multirow{10}{*}{$\begin{array}{l}\text { Problem } \\
\text { confrontation }\end{array}$} & Age & -.091 & 0.197 & 0.257 \\
\hline & Year of schooling & $-.206^{*}$ & & \\
\hline & Household size & -.005 & & \\
\hline & Farm size & .180 & & \\
\hline & Farming experience & $-.223^{*}$ & & \\
\hline & Engagement with FFS & .124 & & \\
\hline & Annual family income & -.030 & & \\
\hline & Extension media contact & $-.215^{*}$ & & \\
\hline & Risk orientation & $-.219^{*}$ & & \\
\hline & $\begin{array}{l}\text { Knowledge on soil and crop } \\
\text { management }\end{array}$ & $-.290^{* *}$ & & \\
\hline
\end{tabular}

* = Significant at 0.05 level, ${ }^{* *}=$ Significant at 0.01 level

The findings indicate that year of schooling $\left(-.206^{*}\right)$, farming experience $\left(-.223^{*}\right)$, extension media contact $\left(-.215^{*}\right)$, risk orientation $\left(-.219^{*}\right)$ and knowledge on soil and crop management $\left(-.290^{* *}\right)$ had significant and negative relationship with problem confrontation.

Year of schooling of the farmers provide broader outlook to gain knowledge on different aspects of crop production. It increases the capability of the farmers to observe and understand a critical situation. And the findings indicate that year of schooling of the FFS farmers had significantly negative relation with their problem confrontation i.e. the FFS higher with high level of education faced lower problems. Karim (2009) and Hossain and Miah (2011) found similar relationship between the concerned variables. Farming experience enables the farmers to understand the farming situations and different farm related problems and the findings may be due to that the FFS farmers having more experience in farming could be more aware of the FFS activities.

Extension media contact had significant and negative relationship with problem confrontation thus, it can be concluded that the FFS farmers having higher contact with extension media faced low problem in participating FFS training sessions. Karim (2009) and Hossain and Miah (2011) also found the similar findings. Based on the findings, the FFS farmers having higher risk orientation towards new agricultural technology faced low problem in participating FFS training sessions. The findings also indicate that the FFS farmers having higher knowledge on soil and crop management opined low problem associated with FFS. Karim (2009) and Hossain and Miah (2011) found the similar relationship in their respective research. 


\section{CONCLUSIONS}

The findings of the present study demonstrate that more than four-fifth of the respondents $(93 \%)$ low to medium problem in participating FFS training sessions. The findings lead to the conclusion that the FFS farmers would be able to harvest more benefits from the FFS if they would be properly executed. It can also be concluded that there is a great chance of involving other than FFS farmers in the FFS activities. Again the findings indicate that year of schooling, farming experience, extension media contact, risk orientation and knowledge on soil and crop management are negatively correlated with the problem confrontation. Therefore, it can be mentioned that there are no significant problems associated with FFS training sessions. But, for increasing the effectiveness of the FFSs and for involving more number of farmers in the FFS activities, the practitioners should take necessary initiatives to minimize the existing problems during training sessions.

\section{REFERENCES}

Bijlmakers, H. 2011. Agricultural Extension Component (AEC)-Agricultural Sector Programme Support (Phase 2).

Bijlmakers, H. and Islam, M. A. 2007. Changing the Strategies of Farmer Field Schools in Bangladesh. LEISA Magazine, 23(4): 21-23.

Braun, A., Jiggins, J., Röling, N., Berg, H. V. D. and Snijders, P. 2006. A Global Survey and Review of Farmer Field School Experiences. Final Report, International Livestock Research Institute, Nairobi, Kenya.

Davis, K. and Place, N. 2003. Non-governmental Organizations as an Important Actor in Agricultural Extension in Semiarid East Africa. Journal of International Agriculture and Extension Education, 10(1): 31-36.

Hossain, M. S. and Miah, M. A. M. 2011. Poor Farmers' Problem Confrontation in Using Manure towards Integrated Plant Nutrition System. Bangladesh Journal of Extension Education, 23(1\&2): 139-147.

Karim, M. D. 2009. Problem Confrontation of Farmers in Using Fertilizers for Rice Production (unpublished master's thesis). Department of Agricultural Extension Education, Bangladesh Agricultural University, Mymensingh.

Khatam, A., Muhammad, S., Choudhury, K. M., Mann, A. A., Haq, I., Khan, Z. U., Idreess, M. and Amin, H. 2010. Strengths and Weakness of Farmer Field Schools Approach as Perceived by Farmers. Sarhad Journal of Agriculture, 26(4): 685-688.

Pontius, J., R. Dilts, and Bartlett, A. 2002. Ten Years of IPM Training in Asia - From Farmer Field Schools to Community IPM. FAO Community IPM Programme, Jakarta.

Saini, R. S. 2008. Guidelines for Conducting Farmer Field School on Improved Package of Practices for Rice. Department of Agriculture and Cooperation, National Food Security Mission, New Delhi, India. 